\title{
Nitrate Reductase Deficient Mutants of Chlamydomonas reinhardii. Biochemical Characteristics
}

\author{
By G. L. NICHOLS,* SAWSAN A. M. SHEHATA† AND P. J. SYRETT \\ Department of Botany and Microbiology, University College of Swansea, \\ Swansea SA2 8PP
}

(Received 29 December 1977; revised 17 March 1978)

\begin{abstract}
Two mutants of Chlamydomonas reinhardii that cannot grow with nitrate as nitrogen source have been examined biochemically. Each mutant differs from the wild-type strain by a single mutation in a Mendelian gene. One mutant (14/15) carries a mutation in a gene designated nit $B$. This organism took up nitrate and converted nitrate-nitrogen to insoluble-nitrogen; nevertheless no enzymic activities associated with nitrate reductase (NADH-nitrate reductase, reduced benzyl viologen nitrate reductase or inducible NADH-cytochrome $c$ reductase) could be demonstrated in frozen/thawed cells or cell-free extracts. At high nitrate concentrations $(5 \mathrm{~mm})$ the rate of nitrate uptake by this mutant $\left[V_{\max } 59 \mathrm{nmol}(\mathrm{mg} \text { dry wt })^{-1} \mathrm{~h}^{-1}\right]$ was considerably lower than that of wild-type $\left[V_{\max } 920 \mathrm{nmol}(\mathrm{mg} \text { dry wt })^{-1} \mathrm{~h}^{-1}\right]$. It is concluded that nit $B$ is probably a regulatory gene for nitrate reductase. The other mutant $(17 / 4)$ has a mutation in a gene designated nit $A$. This organism did not take up nitrate and had no NADH-nitrate reductase or inducible NADH-cytochrome $c$ reductase activities. Frozen/thawed cells and cell-free extracts had reduced benzyl viologen nitrate reductase activity. The enzyme from the nit $A$ mutant eluted from a Sepharose $4 \mathrm{~B}$ column later than wild-type enzyme; it was therefore probably of lower molecular weight. The nit $A$ mutation of $C$. reinhardii closely resembles the nit-3 mutation of Neurospora crassa and, like this mutation, it probably results in loss of the NADH combining sub-unit of nitrate reductase. Strain $137 \mathrm{c}$ of $C$. reinhardii had no enzymic activities associated with nitrate reductase and did not take up nitrate. This organism may have mutations in both the nit $A$ and nitB loci.
\end{abstract}

\section{INTRODUCTION}

The preceding paper (Nichols \& Syrett, 1978) described the isolation, from the alga Chlamydomonas reinhardii, of mutants which cannot grow with nitrate as nitrogen source. Two of these mutants (17/4 and 14/15) were selected for more detailed study and it was shown that each differed from the wild-type strain from which it was derived by a single mutation in a Mendelian gene. The genes carrying these mutations were designated nit $A$ (in 17/4) and nitB (in 14/15). We also examined strain $137 \mathrm{c}$ of $C$. reinhardii. This organism, which has been used by Levine and his colleagues for extensive studies on the genetics of the photosynthetic mechanism (Levine \& Goodenough, 1970), was shown to have two mutations with respect to ability to grow on nitrate (Nichols \& Syrett, 1978).

In this paper we describe some of the biochemical characteristics of these organisms in relation to their ability to take up nitrate and to produce functional nitrate reductase.

* Present address: Department of Biology, Paisley College of Technology, Paisley, Scotland.

$\dagger$ Present address: Department of Botany, College of Science, Al-Azhar University, Cairo, Egypt. 


\section{METHODS}

Growth of organisms. Studies were carried out with Chlamydomonas reinhardii, strain 2192 (wild-type), mutant $17 / 4$ (nit $A$ mutant), mutant 14/15 (nit B mutant) and strain 137c. Only strain 2192 grew with nitrate as nitrogen source (Nichols \& Syrett, 1978). The liquid medium used for growing cultures contained, per litre of double-distilled water, $0.72 \mathrm{~g} \mathrm{KH}_{2} \mathrm{PO}_{4}, 1.44 \mathrm{~g} \mathrm{~K}_{2} \mathrm{HPO}_{4}, 0.02 \mathrm{~g} \mathrm{MgSO}_{4} .7 \mathrm{H}_{2} \mathrm{O}, 0.01 \mathrm{~g} \mathrm{CaCl}_{2} .2 \mathrm{H}_{2} \mathrm{O}$, $10 \mathrm{ml}$ trace element solution (Sueoka, 1960) and $132 \mathrm{mg} \mathrm{N}$ supplied as either $\mathrm{KNO}_{3}$, urea, $\mathrm{KNO}_{3}$ plus urea (equal $\mathrm{N}$ in each) or $\mathrm{NH}_{4} \mathrm{Cl}$. Cultures were grown, usually for $48 \mathrm{~h}$, at $25^{\circ} \mathrm{C}$ in wash bottles fitted with sintered glass bubblers. They were aerated vigorously with air containing $0.5 \%(\mathrm{v} / \mathrm{v}) \mathrm{CO}_{2}$ and illuminated by daylight fluorescent tubes giving a light intensity, at the cultures, of $30 \mathrm{~W} \mathrm{~m}^{-2}$. For enzyme purification, larger volumes of culture were grown in $10 \mathrm{l}$ aspirators.

Determination of rates of nitrate uptake. Organisms grown on urea medium were harvested, washed and suspended in nitrogen-free medium at about $3 \mathrm{mg}$ dry wt $\mathrm{ml}^{-1}$. The suspension was illuminated at $25^{\circ} \mathrm{C}$ and aerated with $\mathrm{CO}_{2}$-enriched air. Nitrate was added at zero time and samples of the culture were removed at suitable intervals (usually 15 or $30 \mathrm{~min}$ ). Some samples were centrifuged immediately and the supernatants were retained for analysis. Others were heated in boiling water for $10 \mathrm{~min}$ and then allowed to stand for $2 \mathrm{~h}$ before centrifuging; this treatment released any nitrate present in the cells. Nitrate in the supernatants was determined by the frozen/thawed Chlorella cell method of Hipkin \& Syrett (1973).

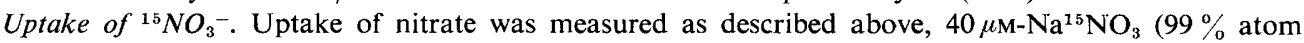
excess) being added at zero time. At zero time and at $4 \mathrm{~h}$ after the addition of ${ }^{15} \mathrm{NO}_{3}{ }^{-}, 10 \mathrm{ml}$ samples of culture were removed, centrifuged and the cells were washed twice with nitrogen-free medium. Some samples of cells were then digested for total-nitrogen determination. Others were extracted with methanol until colourless before being digested; measurements on these samples gave the insoluble-nitrogen. All samples and treatments were in duplicate. Digestion was by a Kjeldahl method using $5 \mathrm{M}$-sulphuric acid containing sodium selenate $\left(20 \mathrm{~g} \mathrm{l}^{-1}\right)$ and $\mathrm{CuSO}_{4} .5 \mathrm{H}_{2} \mathrm{O}\left(20 \mathrm{~g} \mathrm{l}^{-1}\right)$. After digestion, ammonium was collected from each digest in boric acid in a Conway unit (Conway, 1947) and titrated with $0.5 \mathrm{M}-\mathrm{HCl}$. The dried samples of ammonium chloride were analysed for ${ }^{15} \mathrm{~N}$ content by Dr J. W. Millbank of Imperial College, London. Nitrogen gas was generated from the ammonium chloride samples by means of alkaline hypobromite in an apparatus similar to that described by Ross \& Martin (1970). It was analysed by means of an AEI MS2 mass spectrometer.

Preparation of frozen/thawed cells and of cell-free extracts. Organisms were harvested by centrifuging $(1000 \mathrm{~g}$ for $5 \mathrm{~min}$ ), washed twice with nitrogen-free medium and suspended in cold $0.05 \mathrm{M}$-potassium phosphate buffer, $\mathrm{pH} 7 \cdot 5$, containing $5 \mu \mathrm{M}-\mathrm{FAD}$, at about $5 \mathrm{mg}$ dry wt cells $\mathrm{ml}^{-1}$. For the preparation of frozen/thawed cells, portions of this suspension were placed in polypropylene tubes, frozen in liquid nitrogen and stored at $-20^{\circ} \mathrm{C}$. Suspensions were thawed for use without allowing the temperature to rise above $3{ }^{\circ} \mathrm{C}$.

For the preparation of cell-free extract, cell suspension at $3{ }^{\circ} \mathrm{C}$ was passed through a French press (Milner et al., 1950) at $100 \mathrm{MPa}$ and then centrifuged either at $17000 \mathrm{~g}$ for $20 \mathrm{~min}$ or at $90000 \mathrm{~g}$ for $60 \mathrm{~min}$, at $3{ }^{\circ} \mathrm{C}$. The resultant supernatants were used as crude cell-free extracts. Protein was determined by the method of Hartree (1972) using bovine serum albumin as a standard.

Enzyme assays.

(a) $N A D H$-nitrate reductase $(N A D H-N R)$. The reaction mixture $(1 \cdot 3 \mathrm{ml})$ contained either frozen/thawed cells (about 1 to $3 \mathrm{mg}$ dry wt) or cell-free extract (about $500 \mu \mathrm{g}$ protein), $10 \mu \mathrm{mol} \mathrm{KNO}_{3}$ and $0.05 \mathrm{M}$-phosphate buffer, $\mathrm{pH} 7 \cdot 5$, containing $5 \mu \mathrm{M}$-FAD. Incubation was at $30^{\circ} \mathrm{C}$ and the reaction was started by adding $0.6 \mu \mathrm{mol} \mathrm{NADH}$. It was stopped, after $15 \mathrm{~min}$, by adding $0.2 \mathrm{ml} 1 \mathrm{M}$-zinc acetate and $1 \mathrm{ml} 95 \%(\mathrm{v} / \mathrm{v})$ ethanol, and cooling in ice; this treatment removed residual NADH (Medina \& Nicholas, 1957). The tubes were left standing for $10 \mathrm{~min}$ and then agitated and centrifuged. Nitrite in the supernatants was determined spectrophotometrically after addition of Griess-llosvay reagent.

(b) $\mathrm{FMNH}_{2}$-nitrate reductase $\left(\mathrm{FMNH}_{2}-\mathrm{NR}\right)$. The reaction mixture was similar to that for assay of NADHNR but it contained $3.2 \mu \mathrm{mol}$ FMN and the reaction was started by adding $0.25 \mathrm{ml}$ sodium dithionite [ $8 \mathrm{mg} \mathrm{ml}^{-1}$ in $1 \%(\mathrm{w} / \mathrm{v})$ sodium bicarbonate] instead of NADH. The reaction was terminated after $15 \mathrm{~min}$ at $30^{\circ} \mathrm{C}$ by vigorous agitation to oxidize residual dithionite and addition of zinc acetate and ethanol. Nitrite formed was then determined.

(c) Reduced benzyl viologen nitrate reductase $(B V H-N R)$. The method was similar to that of Thacker \& Syrett (1972) but frozen/thawed cells were used and 0.05 M-phosphate/FAD buffer, pH 7.5, was used instead of Tris $/ \mathrm{HCl}$ buffer.

(d) NADH-cytochrome c reductase ( $N A D H-C R)$. Two methods of assay were used. (i) This assay was similar to that of Cove \& Coddington (1965). The assay mixture $(3.0 \mathrm{ml})$ contained $2 \mathrm{mg}$ cytochrome $c$ (horse heart, Grade III), 0.5 to $1.0 \mathrm{ml} 90000 \mathrm{~g}$ cell-free supernatant and $0.05 \mathrm{M}$-phosphate/FAD buffer, $\mathrm{pH} 7 \cdot 5$; after incubation for $5 \mathrm{~min}$ at $30^{\circ} \mathrm{C}$ the reaction was started by adding $2 \cdot 1 \mu \mathrm{mol} \mathrm{NADH}$ and the 
increase in absorbance at $550 \mathrm{~nm}$ was followed. (ii) (Shehata, 1977). The assay mixture (3.0 ml) contained $8 \mathrm{mg}$ cytochrome $c, 0.1$ to $0.5 \mathrm{ml} 17000 \mathrm{~g}$ cell-free supernatant and $0.05 \mathrm{M}$-phosphate buffer, $\mathrm{pH} 7 \cdot 5$, without FAD; after incubation at $30^{\circ} \mathrm{C}$, the reaction was started by adding $0.4 \mu \mathrm{mol} \mathrm{NADH}$ and the reduction of cytochrome $c$ was followed at $550 \mathrm{~nm}$. The quantity of cytochrome $c$ reduced was calculated from the increase in light absorption at $550 \mathrm{~nm}$ using the value for the molar extinction coefficient of cytochrome $c(21000)$ given by Massey (1959).

It was established for all enzyme assays that the reaction was linear with time over the period of measurement and that the rate was proportional to the quantity of enzyme preparation added. Controls with enzyme inactivated by heat were always run.

Purification of nitrate reductase. Cultures grown for $48 \mathrm{~h}$ on urea plus nitrate medium were harvested and cell-free extracts were prepared as described above. The supernatant from centrifugation at $17000 \mathrm{~g}$ was centrifuged again at $100000 \mathrm{~g}$ for $60 \mathrm{~min}$ at $4{ }^{\circ} \mathrm{C}$. The protein which precipitated from this solution at between 30 and $50 \%$ saturation with ammonium sulphate contained most of the nitrate reductase activity. This precipitate was collected by centrifugation at $5000 \mathrm{~g}$, dissolved in $0.05 \mathrm{M}$-phosphate buffer, $\mathrm{pH} 7 \cdot 5$, containing $5 \mu \mathrm{M}$-FAD and used as a partially purified source of the enzyme. Further purification of the enzyme from wild-type strain 2192 was achieved by affinity chromatography on a blue dextran Sepharose 4B column (Solomonson, 1975). The column $(90 \times 15 \mathrm{~mm})$ was equilibrated with buffer A (0.08 M-potassium phosphate, $\mathrm{pH} 7 \cdot 3$, containing $0.15 \mathrm{~mm}$-dithiothreitol, $0.1 \mathrm{~mm}$-EDTA and $5 \mu \mathrm{M}-\mathrm{FAD}$ ). The dissolved ammonium sulphate precipitate was applied to the column and the column washed with buffer $\mathrm{A}$ and then with buffer $\mathrm{B}$ (of similar composition to buffer A but containing $0.4 \mathrm{M}$-phosphate, pH 7.3). Nitrate reductase was then eluted with $0.1 \mathrm{~mm}-\mathrm{NADH}$ dissolved in buffer $\mathrm{A}$. When cytochrome $c$ reductase activity was to be determined in the eluates, FAD was omitted from the elution buffer; in this case, FAD was added to fractions before determination of NADH-NR or $\mathrm{FMNH}_{2}-\mathrm{NR}$ activities.

Nitrate reductase from mutant $17 / 4$ did not bind to the blue dextran affinity column presumably because, as it cannot react with $\mathrm{NADH}$, it lacks the dinucleotide fold (Thompson et al., 1975). Some purification of the enzyme from strain $17 / 4$ was obtained by elution from columns $(500 \times 25 \mathrm{~mm}$, bed volume about $240 \mathrm{ml}$ ) of Sephadex G-200 or Sepharose 4B. These columns were prepared and used following the instructions of the manufacturer (Pharmacia). About $10 \mathrm{mg}$ protein (ammonium sulphate precipitate dissolved in $3 \mathrm{ml}$ phosphate buffer) was applied to the Sephadex column and about $5 \mathrm{mg}$ (in $2 \mathrm{ml}$ buffer) to the Sepharose column. Fractions of $3 \mathrm{ml}$ were collected from the Sephadex column and of $6 \mathrm{ml}$ from the Sepharose column. Extracts from strain 2192 were also run on these columns.

Chemicals. All biochemicals were purchased from Sigma; $\mathrm{Na}^{15} \mathrm{NO}_{3}$ was from Prochem, British Oxygen Company.

\section{RESULTS}

\section{Ability to assimilate nitrat? and to grow with nitrate as nitrogen source}

The nit $A$ mutant (strain 17/4), the nit $B$ mutant (strain 14/15) and strain $137 \mathrm{c}$ could not grow in normal medium with nitrate as nitrogen source but all grew well when urea or ammonium was provided. It was possible that, although unable to grow on nitrate, the mutants might accumulate this ion. Therefore washed suspensions of organisms (2192, $137 \mathrm{c}$ and the nit $A$ and nit $B$ mutants) which had been grown for $48 \mathrm{~h}$ on urea were supplied with nitrate and its disappearance was measured. Samples of the suspensions were removed at intervals and some were heated to release nitrate in the cells into the external medium before analysis. The nit $A$ mutant and strain $137 \mathrm{c}$ showed negligible uptake of nitrate but the wild-type strain 2192 and the nit $B$ mutant took up nitrate (Fig. 1). The nitrate taken up was not retained in the cells because none was released into the medium when the cells were killed by heating. Three-d-old cultures of the nit $B$ mutant had little ability to assimilate nitrate.

Clearly, the nitB mutant took up nitrate but this did not accumulate as nitrate in the cells. This result led to renewed attempts to demonstrate grow th of this mutant on nitrate albeit at a slow rate; these were unsuccessful. Nevertheless, convincing evidence that the nitratenitrogen taken up by the nit $B$ mutant was assimilated into organic nitrogen was obtained by supplying ${ }^{15} \mathrm{NO}_{3}{ }^{-}$at a concentration of $40 \mu \mathrm{M}$. Figure 2 shows the uptake of nitrate by urea-grown organisms of strain 2192 and the nit $A$ and nit $B$ mutants during the experiment. Table 1 shows the incorporation of ${ }^{15} \mathrm{~N}$ into insoluble-nitrogen and total-nitrogen after $4 \mathrm{~h}$. 


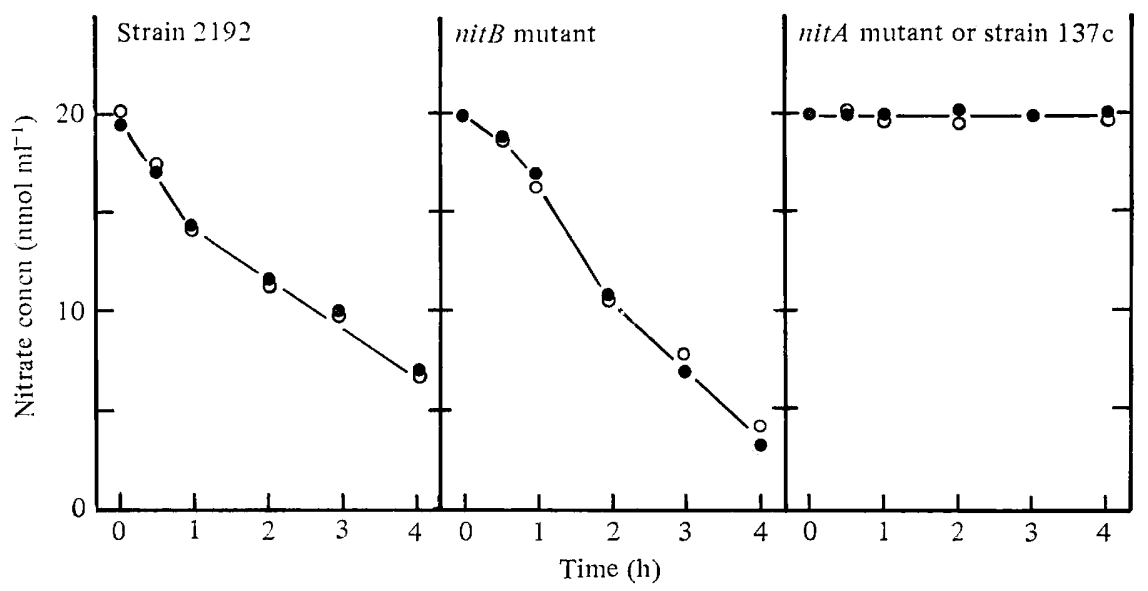

Fig. 1. Nitrate uptake by strain 2192 , the nit $B$ and nit $A$ mutants and strain $137 \mathrm{c}$. Cultures were grown with urea as nitrogen source for $48 \mathrm{~h}$. The initial nitrate concentration was $20 \mu \mathrm{M}$ and the cell density was about $3 \mathrm{mg}$ dry wt $\mathrm{ml}^{-1}$ for each experiment. Nitrate was determined in the supernatants from unheated $(O)$ and heated $(\bullet)$ samples.

\section{Table 1. Assimilation of ${ }^{15} \mathrm{~N}$ from ${ }^{15} \mathrm{NO}_{3}$ - into total-nitrogen and insoluble-nitrogen}

Each value is the mean from determinations on two separate samples; replicate values did not differ by more than $4 \%$. All differences between 'initial' and 'after $4 \mathrm{~h}$ ' values for total-nitrogen and insoluble-nitrogen are significant at the $5 \%$ probability level including those for the nit $A$ mutant.

\begin{tabular}{|c|c|c|c|c|}
\hline Strain & $\begin{array}{r}\text { Nitro } \\
\text { determi }\end{array}$ & $\begin{array}{l}\text { gen } \\
\text { ination }\end{array}$ & $\underset{{ }^{15} \mathrm{~N}_{2}}{\text { Atom }} \%$ & $\begin{array}{c}\text { Atom } \% \\
\text { excess }\end{array}$ \\
\hline \multirow[t]{2}{*}{2192} & Total: & $\begin{array}{l}\text { initial } \\
\text { after } 4 \mathrm{~h}\end{array}$ & $\begin{array}{l}0 \cdot 375 \\
1 \cdot 405\end{array}$ & $\begin{array}{l}0 \\
1 \cdot 033\end{array}$ \\
\hline & Insoluble: & $\begin{array}{l}\text { initial } \\
\text { after } 4 \mathrm{~h}\end{array}$ & $\begin{array}{l}0 \cdot 371 \\
1 \cdot 368\end{array}$ & $\begin{array}{l}0 \\
0.996\end{array}$ \\
\hline \multirow[t]{2}{*}{ nit $A$ mutant } & Total: & $\begin{array}{l}\text { initial } \\
\text { after } 4 \mathrm{~h}\end{array}$ & $\begin{array}{l}0 \cdot 371 \\
0 \cdot 426\end{array}$ & $\begin{array}{l}0 \\
0.054\end{array}$ \\
\hline & Insoluble: & $\begin{array}{l}\text { initial } \\
\text { after } 4 \mathrm{~h}\end{array}$ & $\begin{array}{l}0.376 \\
0.427\end{array}$ & $\begin{array}{l}0 \\
0.055\end{array}$ \\
\hline \multirow[t]{2}{*}{ nit $B$ mutant } & Total: & $\begin{array}{l}\text { initial } \\
\text { after } 4 \mathrm{~h}\end{array}$ & $\begin{array}{l}0 \cdot 374 \\
1 \cdot 033\end{array}$ & $\begin{array}{l}0 \\
0 \cdot 661\end{array}$ \\
\hline & Insoluble: & $\begin{array}{l}\text { initial } \\
\text { after } 4 \mathrm{~h}\end{array}$ & $\begin{array}{l}0.374 \\
0.991\end{array}$ & $\begin{array}{l}0 \\
0 \cdot 617\end{array}$ \\
\hline Checks & $\begin{array}{l}\text { (i) Labora } \\
\text { (ii) Analar }\end{array}$ & $\begin{array}{l}\text { atory air } \\
\left(\mathrm{NH}_{4}\right)_{2} \mathrm{SO}_{4}\end{array}$ & $\begin{array}{l}0.369 \\
0 \cdot 367\end{array}$ & $\begin{array}{l}0 \\
0\end{array}$ \\
\hline
\end{tabular}

Both 2192 and the nit $B$ mutant incorporated ${ }^{15} \mathrm{~N}$ from ${ }^{15} \mathrm{NO}_{3}$; the nit $A$ mutant showed little incorporation.

Figure 3 shows the relationships between rate of nitrate uptake and nitrate concentration in the medium for strain 2192 and the nitB mutant. At low nitrate concentrations the strains did not differ greatly in their ability to assimilate nitrate but at higher concentrations, e.g. $5 \mathrm{~mm}$, the difference was marked. From curves fitted to the points in Fig. 3 by the computer procedure of Bliss \& James (1966), the following kinetic values were obtained: for the nit $B$ mutant, $K_{\mathrm{s}} 255 \mu \mathrm{M}, V_{\max } 59 \mathrm{nmol}(\mathrm{mg} \text { dry wt) })^{-1} \mathrm{~h}^{-1}$; for strain $2192, K_{\mathrm{s}} 674 \mu \mathrm{M}$, $V_{\max } 920 \mathrm{nmol}(\mathrm{mg} \text { dry wt) })^{-1} \mathrm{~h}^{-1}$; where $K_{\mathrm{s}}$ is the nitrate concentration supporting half the maximum rate of uptake. 


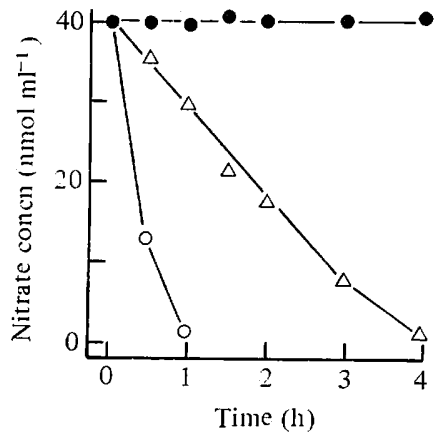

Fig. 2

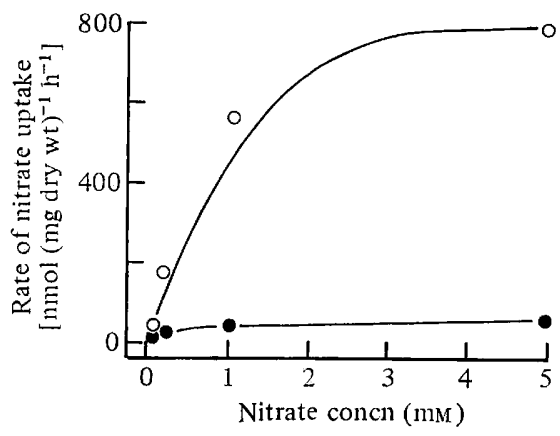

Fig. 3

Fig. 2. Uptake of ${ }^{15} \mathrm{NO}_{3}{ }^{-}$by strain $2192(\bigcirc)$, the nit $B$ mutant $(\triangle)$ and the nit $A$ mutant $(\odot)$. Cultures were grown on $u_{1}$ ea medium for $48 \mathrm{~h}$ and suspensions of washed cells (about $1 \mathrm{mg}$ dry wt ml ${ }^{-1}$ ) were supplied with $\mathrm{Na}^{15} \mathrm{NO}_{3}$ at an initial concentration of $40 \mu \mathrm{M}$. Samples were removed at zero time and after $4 \mathrm{~h}$ for measurement of ${ }^{15} \mathrm{~N}$ incorporation (see Table 1 ).

Fig. 3. The relationship between rate of nitrate uptake and nitrate concentration for strain 2192 $(O)$ and the nit $B$ mutant ( $)$. Conditions were similar to those for the experiments of Fig. 1 . Replicate samples of each culture were supplied with nitrate to give the initial concentrations shown on the abscissa. Nitrate was determined in samples removed at intervals (over $8 \mathrm{~h}$ for the lower nitrate concentrations, and over $24 \mathrm{~h}$ for the higher ones). The graphs of nitrate concentration against time were reasonably linear and the rates plotted in the figure were obtained from their slopes. The hyperbolae drawn were fitted by the iterative computer procedure of Bliss \& James (1966). They give the following kinetic values: for the nit $B$ mutant, $K_{\mathrm{8}} 255 \mu \mathrm{M}, V_{\max } 59 \mathrm{nmol}$ (mg dry wt) $)^{-1} \mathrm{~h}^{-1}$; for strain $2192, K_{\mathrm{s}} 674 \mu \mathrm{M}, V_{\max } 920 \mathrm{nmol}\left(\mathrm{mg}\right.$ dry $\mathrm{wt}^{-1} \mathrm{~h}^{-1}$.

Table 2. NADH-nitrate reductase and BVH-nitrate reductase activities in frozen/thawed cell preparations of wild-type (strain 2192) and three mutant strains

Cultures were grown for $48 \mathrm{~h}$ on urea medium, and then organisms were harvested, washed and incubated for $5 \mathrm{~h}$ in medium containing the nitrogen sources shown before being taken for enzymic analysis. Activities are expressed as nmol nitrite formed $\min ^{-1}(10 \mathrm{mg} \text { cell dry wt })^{-1}$. Mean values are given based on the number of separate determinations indicated in parentheses.

Enzyme activity

\begin{tabular}{llrc}
\multicolumn{1}{c}{ Strain } & Nitrogen source & BVH-NR & NADH-NR \\
2192 & Urea & $1 \cdot 8(2)$ & $0 \cdot 6(3)$ \\
& Urea + nitrate & $26 \cdot 7(3)$ & $18 \cdot 6(3)$ \\
& None & $8 \cdot 9(2)$ & $2 \cdot 3(3)$ \\
& Ammonium & $0 \cdot 9(2)$ & ND \\
$137 \mathrm{c}$ & Ammonium + nitrate & $6 \cdot 6(1)$ & ND \\
& Urea & $*(2)$ & $*(2)$ \\
& Urea + nitrate & $*(2)$ & $*(2)$ \\
nit $B$ mutant & None & $3 \cdot 3(2)$ & $0 \cdot 2(2)$ \\
& Urea & $0 \cdot 3(2)$ & $0 \cdot 6(2)$ \\
& Urea + nitrate & $*(2)$ & $0 \cdot 2(2)$ \\
nit $A$ mutant & None & $6 \cdot 4(2)$ & $0 \cdot 4(2)$ \\
& Urea & $1 \cdot 7(3)$ & $0 \cdot 1(3)$ \\
& Urea +nitrate & $46 \cdot 6(4)$ & $0 \cdot 1(3)$ \\
& None & $69 \cdot 8(3)$ & $0 \cdot 3(3)$ \\
& Ammonium & $*(1)$ & ND \\
& Ammonium + nitrate & $22 \cdot 8(1)$ & ND
\end{tabular}

* No activity detected. ND, Not determined. 


\section{Table 3. Enzymic activities in cell-free extracts}

Cultures were grown for $48 \mathrm{~h}$ in medium containing the nitrogen source shown and then cell-free extracts were prepared. These extracts contained about $1 \mathrm{mg}$ protein $\mathrm{ml}^{-1}$. NADH-CR activity was measured by assay (ii). Specific activities are expressed as nmol product formed $\mathrm{min}^{-1}$ $(\mathrm{mg} \text { protein })^{-1}$.

\begin{tabular}{llccc}
\multirow{1}{*}{ Strain } & & \multicolumn{3}{c}{ Enzyme specific activity } \\
2192 & Nitrogen source & NADH-NR & FMNH $_{2}$-NR & NADH-CR \\
& Nitrate & 80 & 65 & 21 \\
& Nitrate + urea & 80 & 68 & 55 \\
& Urea & 3 & $1 \cdot 0$ & 16 \\
nit $B$ mutant & Ammonium & 1 & $0 \cdot 3$ & 9 \\
nit $A$ mutant & Urea+nitrate & 0 & 0 & 18 \\
& Urea + nitrate & 0 & $2 \cdot 3$ & 18
\end{tabular}

\section{Presence or absence of nitrate reductase activity}

Nitrate reductase catalyses three enzymic activities, namely (i) NADH-NR, reduction of nitrate with NADH as electron donor, (ii) BVH-NR or $\mathrm{FMNH}_{2}-\mathrm{NR}$, reduction of nitrate with reduced benzyl viologen or $\mathrm{FMNH}_{2}$ as electron donor, and (iii) NADH-CR, reduction of cytochrome $c$ with NADH as electron donor (Beevers \& Hageman, 1969). Table 2 gives nitrate reductase activities measured with cells grown on urea for $48 \mathrm{~h}$, incubated with nitrogen source for $5 \mathrm{~h}$ and then frozen/thawed. Where low apparent activities were recorded they have been included in the table but little significance is attached to these values. Cells of wild-type 2192 contained detectable NADH-NR and BVH-NR activities when incubated with urea. These activities were much higher when nitrate was present in the incubation medium but lower with ammonium; the activities also increased when urea-grown cell were incubated for $5 \mathrm{~h}$ in the absence of a nitrogen source. In strain $137 \mathrm{c}$ and in the nit $B$ mutant, activities were always low; there is a suggestion that a low BVH-NR activity developed in both during nitrogen starvation but this may not be real. The nitA mutant had no NADH-NR activity but it had substantial BVH-NR activity which increased during incubation with nitrate and even more so during $5 \mathrm{~h}$ incubation with no nitrogen source; the activity was lower when the medium contained ammonium in addition to nitrate. Similar results were obtained from less extensive assays using cell-free extracts from cells grown on urea/nitrate medium (Table 3 ).

\section{NADH-cytochrome c reductase activity}

Nitrate reductase catalyses the reduction of cytochrome $c$ with NAD(P)H as electron donor, but this reaction can also be catalysed by other enzymes (MacDonald et al., 1974). Crude cell-free extracts from 2192 and from both mutants had this activity (Table 3). Cells of 2192 incubated for $5 \mathrm{~h}$ with urea plus nitrate contained much more NADH-CR activity than cells incubated with urea alone (Table 4). In contrast, the presence of nitrate during the incubation did not affect the activity of cells of strain $137 \mathrm{c}$ or the nit $A$ and nit $B$ mutants; it appears probable, therefore, that these organisms lack the NADH-CR activity that is specifically associated with nitrate reductase.

\section{Purification of nitrate reductase from strain 2192 and the nit A mutant}

Table 5 records the partial purification of nitrate reductase from strain 2192 using a blue dextran affinity column. The specific activities of $\mathrm{NADH}-\mathrm{NR}$ and $\mathrm{FMNH}_{2}-\mathrm{NR}$ were increased about 200 -fold during purification. The purified enzyme retained NADH-CR activity. 
Table 4. NADH-cytochrome c reductase activity in cell-free extracts of wild-type (strain 2192) and three mutant strains

Cultures were grown for $48 \mathrm{~h}$ on urea medium, and then organisms were harvested and incubated for $5 \mathrm{~h}$ in medium containing the nitrogen source shown before preparation of cell-free extracts for assay. NADH-CR activity was measured by assay (i) and is expressed as nmol cytochrome $c$ reduced $\mathrm{min}^{-1}$ ( $\mathrm{mg}$ protein $)^{-1}$. Mean values are given based on the number of separate determinations indicated in parentheses.

\begin{tabular}{|c|c|c|c|}
\hline Strain & Nitrogen source & $\begin{array}{c}\text { NADH-CR } \\
\text { activity }\end{array}$ & $\frac{\text { Induced CR }}{\text { Non-induced CR }}$ \\
\hline 2192 & $\begin{array}{l}\text { Urea } \\
\text { Urea+ nitrate }\end{array}$ & $\begin{array}{l}19 \cdot 8(6) \\
56.9(6)\end{array}$ & $2 \cdot 9$ \\
\hline $137 \mathrm{c}$ & $\begin{array}{l}\text { Urea } \\
\text { Urea + nitrate }\end{array}$ & $\begin{array}{l}13 \cdot 0(5) \\
13 \cdot 6(5)\end{array}$ & $1 \cdot 0$ \\
\hline nit $B$ mutant & $\begin{array}{l}\text { Urea } \\
\text { Urea+ nitrate }\end{array}$ & $\begin{array}{r}14 \cdot 6(4) \\
8 \cdot 7(4)\end{array}$ & $0 \cdot 6$ \\
\hline nit $A$ mutant & $\begin{array}{l}\text { Urea } \\
\text { Urea + nitrate }\end{array}$ & $\begin{array}{l}27 \cdot 3(2) \\
22 \cdot 2(2)\end{array}$ & $0 \cdot 8$ \\
\hline
\end{tabular}

Using a Sepharose 4B column, nitrate reductase from strain 2192 was purified about 30 -fold; again the partially purified preparation retained NADH-CR activity. Table 6 summarizes the purification of the $\mathrm{FMNH}_{2}-\mathrm{NR}$ enzyme from the nitA mutant on Sepharose 4B. Two points are noteworthy. Firstly, a marked increase in $\mathrm{FMNH}_{2}-\mathrm{NR}$ activity occurred during ammonium sulphate precipitation; this has been noted several times and presumably results from an activation phenomenon. A similar, but less marked, increase was found with extracts from 2192. Secondly, in our system the nitrate reductase from strain 2192 eluted from the Sepharose column in fractions 8 to 11 , very close to the blue dextran marker, whereas the $\mathrm{FMNH}_{2}-\mathrm{NR}$ activity from the nit $A$ mutant eluted later, in fractions 20 to 22 . The later elution indicates that the enzyme in this mutant is of lower molecular weight than that from 2192 .

\section{Apparent $K_{\mathrm{m}}$ values for nitrate reduction}

The relationship between nitrate concentration and rate of nitrate reduction was investigated using enzymes partially purified by ammonium sulphate precipitation and either $\mathrm{NADH}$ or $\mathrm{FMNH}_{2}$ as electron donors. During assays, incubations were for $10 \mathrm{~min}$ and the quantity of nitrite formed was determined; even at the lowest nitrate concentrations the quantity of nitrate reduced was less than $30 \%$ of the total present in the reaction mixture. Hyperbolae were fitted to the plots of rate of nitrite formation against nitrate concentration by the computer procedure of Bliss \& James (1966). The computer also gave the following apparent $K_{\mathrm{m}}$ values for nitrate: for enzyme from strain $2192,412 \pm 89 \mu \mathrm{M}$ with NADH as electron donor and $1900 \pm 244 \mu \mathrm{M}$ with $\mathrm{FMNH}_{2}$; for enzyme from the nitA mutant. $284 \pm 33 \mu \mathrm{M}$ with $\mathrm{FMNH}_{2}$ as electron donor.

\section{DISCUSSION}

The three strains we have examined differ from each other and from wild-type both genetically (Nichols \& Syrett, 1978) and biochemically. Unlike wild-type, none of them is able to grow with nitrate as nitrogen source.

The nit $A$ mutant differs from wild-type by a mutation in a single Mendelian gene. Biochemically it has lost NADH-NR and NADH-CR activities but retains BVH(FMNH activity. This enzymic activity, however, confers no ability for intact cells to utilize nitrate. They do not take up nitrate and do not assimilate ${ }^{15} \mathrm{~N}$ from ${ }^{15} \mathrm{NO}_{3}{ }^{-}$to any appreciable 


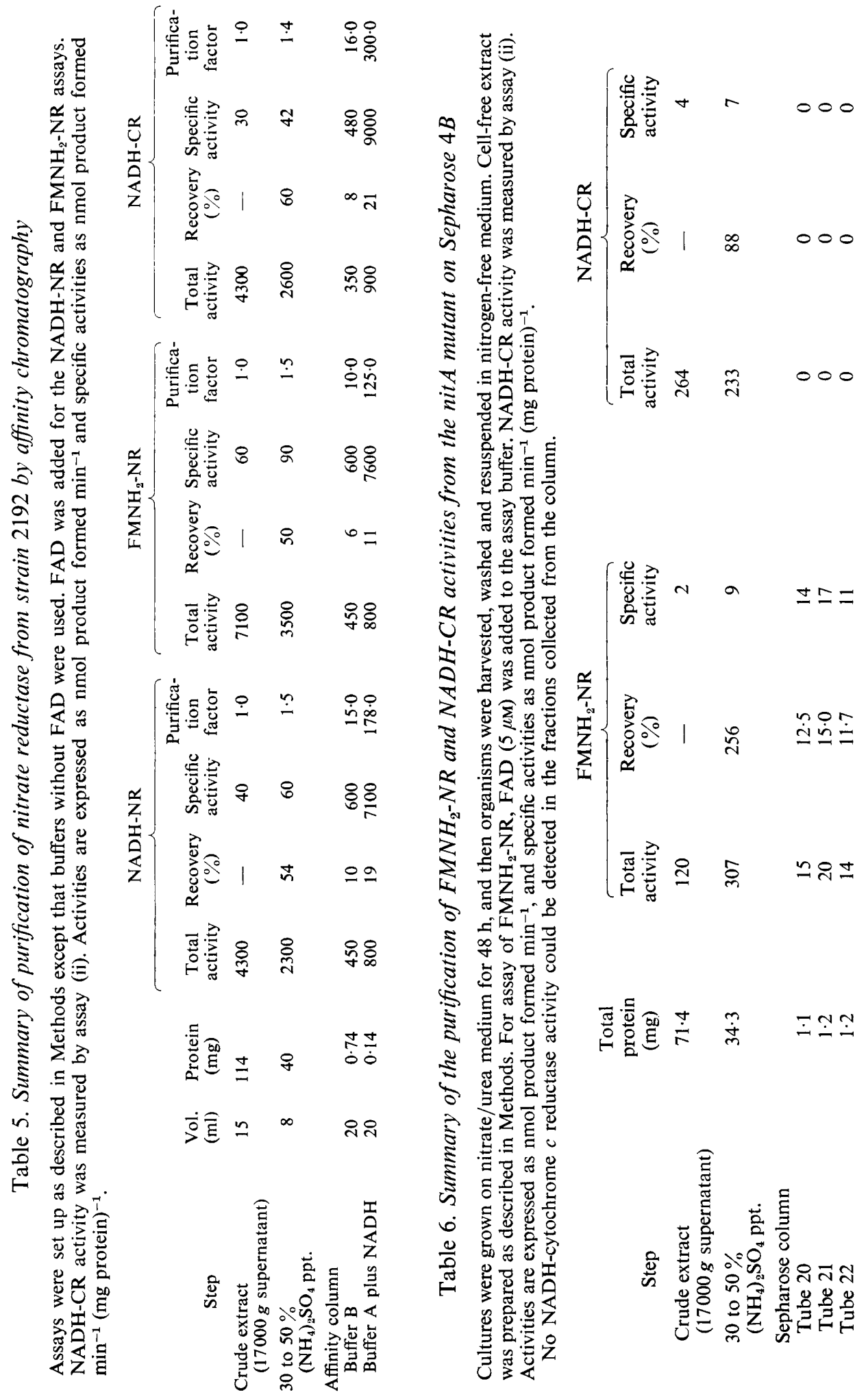


extent. This mutant grows well on hypoxanthine and this finding supports the view that the $\mathrm{BVH}\left(\mathrm{FMNH}_{2}\right)-\mathrm{NR}$ activity is associated with the molybdenum-containing sub-unit of nitrate reductase (Coddington, 1976). The nitrate reductase from the nitA mutant elutes later than nitrate reductase from wild-type from a Sepharose column. It is therefore presumably of lower molecular weight than the wild-type enzyme and it is reasonable to suggest that it has lost the sub-unit of the enzyme which combines with NADH (Barea et al., 1976). Phenotypically our nitA mutant corresponds closely to the nit-3 mutant of Neurospora crassa (Coddington, 1976) which also produces a BVH-nitrate reductase of lower molecular weight than enzyme from wild-type and which has also lost NAD(P)H-NR and NAD(P)H$\mathrm{CR}$ activities. In both mutants, BVH-nitrate reductase activity, under inducing conditions, was higher than that of wild-type under similar conditions and in both, the nitrate reductase, like that of the wild-type strains, was repressed in the presence of ammonium. It is probable, therefore, that the nit $A$ mutation in $C$. reinhardii is similar to that in $N$. crassa nit-3 and is a mutation in a structural gene for nitrate reductase.

The nitB mutant also differs from wild-type by a single mutation. Biochemically this organism has no enzymic activities associated with nitrate reductase that can be assayed except possibly a little BVH-NR activity in nitrogen-starved cells. Nevertheless this organism can take up nitrate. At high nitrate concentrations the rate of uptake is considerably lower than that of wild-type, but at low nitrate concentrations their rates of uptake are not too dissimilar; there is no doubt that this mutant, like wild-type, can assimilate ${ }^{15} \mathrm{~N}$ from ${ }^{15} \mathrm{NO}_{3}{ }^{-}$into insoluble-nitrogen. Therefore the nit $B$ mutant must reduce nitrate. Since the $\mathrm{BVH}\left(\mathrm{FMNH}_{2}\right)-\mathrm{NR}$ activity in the nit $A$ mutant does not allow intact cells of this organism to assimilate nitrate, we conclude that the nit $B$ mutant must possess some NADH-reductase activity although we have failed to find any despite several attempts with concentrated cellfree extracts. Similarly the failure of the nitB mutant to grow, albeit slowly, with nitrate as a nitrogen source is puzzling. This mutant clearly requires further investigation. At present we suggest that nit $B$ is a regulatory gene and that a mutation in this gene has depressed nitrate reductase formation in strain $14 / 15$.

Strain $137 \mathrm{c}$ is the strain which has been much used by Levine and his colleagues (Levine $\&$ Goodenough, 1970). It differs from wild-type 2192 with respect to growth on nitrate by two mutations (Nichols \& Syrett, 1978). Biochemically it lacks all the nitrate-inducible activities associated with nitrate reductase and does not take up nitrate. It does grow with hypoxanthine as nitrogen source and this suggests that it can produce a normal molybdenumcontaining sub-unit which is believed to be necessary for NADH-NR, BVH(FMNH $\left.{ }_{2}\right)-\mathrm{NR}$ and xanthine dehydrogenase (Pateman et al., 1964). Crosses of $137 \mathrm{c}$ with either the nit $A$ or nitB mutants did not show any wild-type recombinants (Nichols \& Syrett, 1978). Possibly, then, strain $137 \mathrm{c}$ has mutations in both the nit $A$ and nit $B$ genes.

The work described in this and the preceding paper (Nichols \& Syrett, 1978) is, to our knowledge, the first that has attempted to study nitrate reduction in a eukaryotic alga by the methods of biochemical genetics. Our information is, as yet, much more limited than that available from studies with fungi, but one interesting difference is now apparent. Biochemically, the nit $A$ mutant of $C$. reinhardii closely resembles the nit-3 mutant of $N$. crassa in that both have BVH-nitrate reductase activity but both are unable to assimilate nitrate. The nit-3 mutant of $N$. crassa does, however, take up and accumulate nitrate (Schloemer \& Garrett, 1974). Our initial experiments with the nitA mutant of C. reinhardii were based on the expectation that it, too, would accumulate nitrate. It does not, and experiments using radioactive chlorate as an analogue of nitrate (Shehata, 1977) have failed to show any uptake into cells of $C$. reinhardii that lack a functional nitrate reductase. It may be that $C$. reinhardii is unlike $N$. crassa in that the nitrate reductase protein is responsible not only for nitrate reduction but also for nitrate uptake. The suggestion that this is so in some organisms has been put forward by Butz \& Jackson (1976). One might then take this idea further and suggest that our nitB mutant, which lacks any detectable 
nitrate reductase activity, may also lack an uptake system for nitrate. Certainly this view would be consistent with the low maximum rate of nitrate uptake by this strain.

Note added in proof. Sosa, Ortega \& Barea (Plant Science Letters, 1978, 11, 51-58) have recently isolated nitrate reductase deficient mutants of Chlamydomonas reinhardii. The mutants were not genetically analysed but their biochemical characteristics were determined. One group of mutants was similar to our nit $A$ mutant and another may be the same as our nit $B$ mutants. They did, however, isolate two further groups of mutants that differ biochemically from those we describe.

One of us (S. A.M.S.) thanks the Government of Egypt for financial assistance. We thank Dr J. W. Millbank of Imperial College, London, for carrying out the ${ }^{15} \mathrm{~N}$ determinations.

\section{REFERENCES}

Barea, J. L., Maldonado, J. M. \& Cardenas, J. (1976). Further characterization of nitrate and nitrite reductases from Chlamydomonas reinhardii. Physiologia plantarum 36, 325-332.

BeEvers, L. \& Hageman, R. H. (1969). Nitrate reduction in higher plants. Annual Review of Plant Physiology 20, 495-522.

Bliss, G. I. \& JAMES, A. T. (1966). Fitting the rectangular hyperbola. Biometrics 22, 573602.

Burz, R. G. \& Jackson, W. A. (1976). A mechanism for nitrate transport and reduction. Phytochemistry 16, 409-417.

Coddington, A. (1976). Biochemical studies on the nit mutants of Neurospora crassa. Molecular and General Genetics 145, 195-206.

Conway, E. J. (1947). Microdiffusion Analysis and Volumetric Error. London: Crosby Lockwood \& Son.

Cove, D. J. \& Coddington, A. (1965). Purification of nitrate reductase and cytochrome $c$ reductase from Aspergillus nidulans. Biochimica et biophysica acta 110, 312-318.

Hartree, E. F. (1972). A modification of the Lowry method that gives a linear photometric response. Analytical Biochemistry 48, 422-427.

Hipkin, C. R. \& SyretT, P. J. (1973). Enzymic determination of nitrate by use of frozen/thawed Chlorella cells. New Phytologist 72, 47-49.

Levine, R. P. \& Goodenough, U. (1970). The genetics of photosynthesis and of the chloroplast in Chlamydomonas reinhardi. Annual Review of Genetics 4, 397-408.

MacDonald, D. W., Cove, D. J. \& Coddington, A. (1974). Cytochrome $c$ reductases from wild-type and mutant strains of Aspergillus nidulans. Molecular and General Genetics 128, 187-199.

MASSEY, V. (1959). The microestimation of succinate and the extinction coefficient of cytochrome $c$. Biochimica et biophysica acta 34, 255-256.
Medina, A. \& Nicholas, D. J. D. (1957). Interference by reduced pyridine nucleotides in the diazotization of nitrite. Biochimica et biophysica acta 33, 440-442.

Milner, H. W., Lawrence, N. S. \& French, C. S. (1950). Colloidal dispersion of chloroplast material. Science 111, 633-634.

Nichols, G. L. \& SyretT, P. J. (1978). Nitrate reductase deficient mutants of Chlamydomonas reinhardii. Isolation and genetics. Journal of General Microbiology 108, 71-77.

Pateman, J. A., Cove, D. J., Rever, B. M. \& RoBerTs, D. B. (1964). A common co-factor for nitrate reductase and xanthine dehydrogenase which also regulates the synthesis of nitrate reductase. Nature, London 201, 58-60.

Ross, P. J. \& MARTIN, A. E. (1970). A rapid procedure for preparing gas samples for nitrogen-15 determination. Analyst 95, 817-822.

Schloemer, R. H. \& GarketT, R. H. (1974). Nitrate transport system in Neurospora crassa. Journal of Bacteriology 118, 259-269.

Shenata, S. A. M. (1977). Mechanisms for the uptake and m?tabolism of nitrate by Chlamydomonas. Ph.D. thesis, University of Wales.

Solomonson, L. P. (1975). Purification of NADHnitrate reductase by affinity chromatography. Plant Physiology 56, 853-855.

SueokA, N. (1960). Mitotic replication of deoxyribonucleic acid in Chlamydomonas reinhardi. Proceedings of the National Academy of Sciences of the United States of America 46, 83-91.

ThACKer, A. \& SYretT, P. J. (1972). Disappearance of nitrate reductase activity from Chlamydomonas reinhardi. New Phytologist 71, 435-441.

Thompson, S. T., Cass, K. H. \& Stellwegen, E. (1975). Blue dextran-Sepharose: an affinity column for the dinucleotide fold in proteins. Proceedings of the National Academy of Sciences of the United States of America 72, 669-672. 